\title{
BIOLOGICAL AND ENVIRONMENTAL REQUISITES FOR A SUCCESSFUL TRAP FISHERY OF THE NORTHERN SHRIMP Pandalus borealis
}

\author{
P. KOELLER ${ }^{1 *}$, M. COVEY ${ }^{1}$ and M. KING ${ }^{2}$ \\ ${ }^{1}$ Population Ecology Division, Science Branch \\ Department of Fisheries and Oceans, Maritimes Region \\ Bedford Institute of Oceanography \\ PO Box 1006 \\ Dartmouth, Nova Scotia B2Y $4 A 2$ \\ ${ }^{2} 2261$ Fox Island, RR \#1 Canso
Guysborough Co, NS BOH $1 \mathrm{HO}$
}

A permanent trap fishery for northern pink shrimp (Pandalus borealis) was established in Chedabucto Bay, Nova Scotia in 1996 after several years of experimental trapping by one fisherman. Despite extensive experimental trapping projects elsewhere in Nova Scotia, only in one other area, Mahone Bay, has a long-term fishery been successfully established. The successful trapping of shrimp from small vessels off the coast of Nova Scotia appears to be dependant on a number of requisite conditions, including the presence of soft mud habitat and low temperatures in large, relatively deep coastal embayments. Catch rates for the established inshore trap fisheries increase in late summer-fall and decrease in spring, suggesting that an inshore migration occurs in the fall from adjacent "feeder" populations. In addition to the seasonal pattern of trap catches, cyclical changes at a finer temporal scale were observed that appear to be related to tidal cycles, with higher catch rates associated with greater tidal ranges. Coupled with known diurnal vertical migratory behaviour, this pattern could arise as more water, and the shrimp within it, pass horizontally over the trap and come into contact with its bait plume during greater tidal ranges. More complex, selective vertical migration coupled with tidal drift may result in net movement into areas such as Chedabucto Bay. Analysis of length at sex transition and maximum size suggests that shrimp trapped in Chedabucto Bay come from the same population as those caught by trawlers inshore and offshore on the eastern Scotian Shelf. Shrimp trapped in Mahone Bay and St. Margaret's Bay have significantly different growth characteristics and are probably from a different population. Thus the Mahone Bay and St. Margaret's Bay population appears to be more locally confined than the widespread shrimp population on the eastern Scotian Shelf, possibly originating from areas within and immediately adjacent to these bays.

Une pêche annuelle de la crevette nordique (Pandalus borealis) au casier a été établie dans la baie Chedabucto (Nouvelle-Écosse) en 1996, après plusieurs années de pêche expérimentale au casier par un pêcheur. Malgré les nombreux projets de pêche expérimentale au casier menés ailleurs dans la province, une pêche à long terme a été établie avec succès dans seulement un autre secteur (la baie Mahone). La réussite de la pêche de la crevette au casier par les petits bateaux au large de la côte de la Nouvelle-Écosse semble dépendre d'un certain nombre de conditions, y compris la présence d'un habitat vaseux mou et de basses températures dans de grandes échancrures relativement profondes de la côte. Les taux de capture pour les pêches côtières au casier établies augmentent à la fin de l'été et à l'automne et baissent

* Author to whom correspondence should be addressed

E-mail: koellerp@mar.dfo-mpo.gc.ca 
au printemps, ce qui suggère que les crevettes migrent de populations sources vers la côte à l'automne. En plus de ce profil saisonnier des prises dans les casiers, des changements cycliques à une échelle temporelle plus fine ont été observés et ceux-ci semblent liés au cycle de marée, le taux de capture étant plus élevé lorsque l'amplitude de la marée est grande. Combiné au comportement de migration verticale diurne, ce profil pourrait survenir quand la quantité d'eau (et les crevettes qu'elle contient) qui passe horizontalement au-dessus des casiers est grande et qu'elle entre en contact avec le panache d'attractifs des casiers durant les périodes de grande amplitude de la marée. Une migration verticale sélective plus complexe combinée à une dérive tidale pourrait donner lieu à un mouvement net vers les secteurs comme la baie Chedabucto. L'analyse de la longueur au moment du changement de sexe et de la taille maximale suggère que les crevettes piégées dans la baie Chedabucto appartiennent à la même population que celles capturées par les chalutiers en milieux côtiers et extracôtiers dans la partie est du plateau néo-écossais. Les crevettes piégées dans les baies Mahone et St. Margaret's ont des caractéristiques de croissance considérablement différentes et font probablement partie d'une autre population. Ainsi, la population des baies Mahone et St. Margaret's semble avoir une aire de répartition beaucoup plus limitée que la population étendue de crevettes dans la partie est du plateau néo-écossais, et elle provient peut-être de secteurs à l'intérieur de ces baies ou adjacents à celles-ci.

\section{INTRODUCTION}

Late in 2006 Mike Newell, a fisherman from Canso, Nova Scotia, died at sea while tending to shrimp traps in the small but thriving fishery he founded. This paper, and a companion article published in the Bedford Institute of Oceanography's annual Science Review, are dedicated to him. Much of the data used were collected by him during his experimental and commercial fishing endeavours.

Pandalus borealis, the northern pink shrimp, is a circumpolar species. On the Scotian Shelf it is near the southern limit of its distribution where commercial concentrations are currently restricted mainly to the cold, deep water of the eastern Scotian Shelf. It is a protandric hermaphrodite, which spends approximately its first four years as a male, then changes to the female at about $20 \mathrm{~mm}$ carapace length. The larger females usually comprise the bulk of the commercial catch. The fishery for northern shrimp in the Maritime Provinces first began in the mid 1960s off Grand Manan Island in the Bay of Fundy. By the end of the decade catches had dwindled and the shrimp trawlers moved to an area off southwest Nova Scotia known as the Roseway Basin. Shrimp catches in this area also could not be sustained and the fishery ended by 1972 (Koeller 2000). In the late 1970s commercial concentrations of shrimp were discovered on the eastern Scotian Shelf. Although shrimp trawl licences were issued, the resource was under-exploited for many years, initially due to market conditions, but later due to by-catches of groundfish under quota management. This problem was solved in the early 1990s with the introduction of the Nørdmore grid, a device which allows most fish to escape capture. As a result, trawl catches increased to the total allowable catch (TAC) of $3,000 \mathrm{mt}$ for the first time in 1994 (Koeller et al. 2006). At the same time 
abundance and trawl catch rates also increased, indicating the possibility of additional fishing capacity and licenses.

In the early 1990s Mike Newell traveled to New England to research the shrimp trap fishery there. He realized that biological and oceanographic conditions off Canso could be similar to those in Maine where a winter, coastal trap fishery had been conducted since 1971, apparently facilitated by a fall-winter inshore migration of larger shrimp, especially egg-bearing females (Schick 1982). A new inshore fishery would help alleviate the economic hardships, particularly acute in Canso, caused by the groundfish fisheries closures. By 1996 he had demonstrated the economic viability and sustainability of shrimp trapping off Canso, resulting in the issuance of permanent trap licences.

Under co-operative government-industry scientific monitoring and management, the shrimp trawl and trap fisheries on the eastern Scotian Shelf appear to be sustainable under the present management and oceanographic regimes. Abundance has remained high and in 2006 commercial trawler catch rates were the highest recorded (Koeller et al. 2006). Since $~ 95 \%$ of the shrimp TAC is taken by trawlers, most of the scientific and managerial effort has been associated with this sector, as described in Research Documents of the Canadian Science Advisory Secretariat (http://www.dfo-mpo. gc.ca/csas/csas/Publications/Pub_Index_e.htm). This paper attempts to balance the scientific record to some degree by using data collected by trap fishers to describe their fishery. In particular, it describes the biological and environmental characteristics of the areas of successful shrimp trapping in Nova Scotia. It is hoped that this will help in the planning and conduct of future exploratory shrimp trapping projects, and increase their chances of success.

\section{METHODS}

Trap data, including fishing location, depth, number of traps fished and catch weight were recorded on official shrimp trap monitoring documents issued by the Department of Fisheries and Oceans to all fishers holding experimental or permanent shrimp trap licences. Monitoring document completion and submission is mandatory for all shrimp fishers and conditional to licensing. These data were accessed from the Maritimes Fisheries Information System (MARFIS), a confidential computer database maintained by DFO. A number of fishers holding experimental licences were issued continuously recording data loggers (AMIRIX Systems Inc. http://www.vemco.com/) to determine temperature at fishing depth. These were attached to one or several traps and periodically downloaded and re-deployed. Experimental fishers also recorded additional information such as per-trap catch weights (instead of per-string as normally recorded) and bycatch information. Samples of shrimp, generally about $4 \mathrm{~kg}$ and $\sim 500$ shrimp) were collected, frozen and returned to the laboratory to determine the biological characteristics of the catch. This information is on the DFO Science Branch Virtual Data Centre 
(VDC) and is available to DFO researchers and other interested parties on request. The shrimp database is described in Hunter \& Koeller (1997).

All fishers in the experimental and commercial phases of the trap fishery used the modified Maine trap specified in experimental and commercial licence conditions (Koeller et al. 1995), (Fig 1). Crab excluder devices (entrance size restricted to exclude most crabs but allow shrimp to enter) were used in areas where crab bycatch was a problem, e.g. off Canso because small female snow crabs prevent shrimp from entering traps. In general traps are deployed in strings of 5-10 traps, with 10 traps being the most common. Bait usually consisted of salted herring or mackerel, often rotted and macerated to facilitate spread of the attractive scent plume. It is necessary to hang the small-meshed bait bag so that it partly protrudes from the entrance (Figs 1,2) - bait placed entirely inside the trap usually results in few or no shrimp caught. Observations by Mike Newell and Peter Koeller from Department of National Defense submersibles Pisces and SDL-1 off Canso and Louisbourg in 1995 and 1996 showed that shrimp enter traps slowly, first testing the bait bag at the entrance, then working their way along it into the trap as they feed (Fig 2).

Additional information on shrimp distribution and biological characteristics on the Scotian Shelf is available from several other sources, including groundfish, shrimp and crab surveys using trawls with small mesh liners that retain shrimp. All data sources used in the paper are detailed in Table 1 and are readily available to researchers.

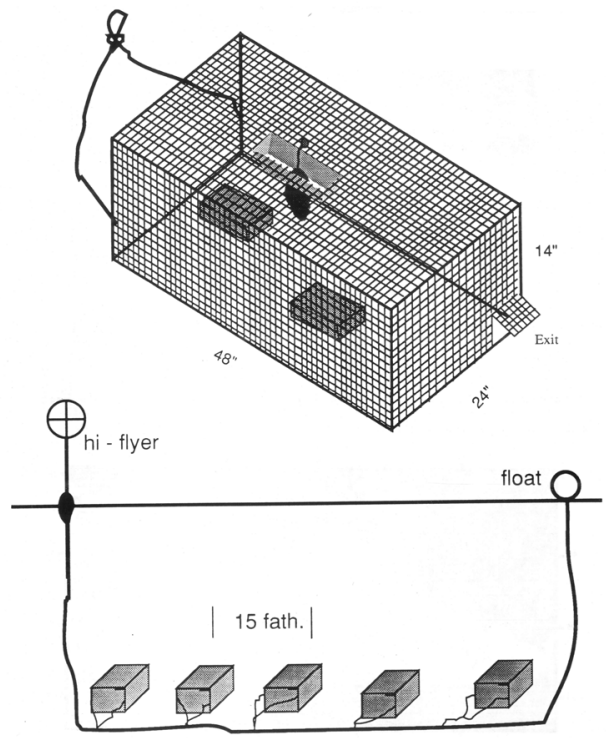

Fig 1. Modified Maine shrimp trap made of $1 \times 0.5$ inch plastic-coated wire mesh. The drawing also shows the fishing and baiting method (bait bag protruding from trap entrance). Concrete blocks are used for ballast, and a trap door in one corner is used to shake out trapped shrimp. 
Table 1 Shrimp catch and biological data sources used in this report. The time spans refer to the dates when shrimp data was available and not necessarily the time span of the entire series. For example, the groundfish survey series began in 1974, but shrimp data was not collected quantitatively until 1999.

\begin{tabular}{|c|c|c|c|}
\hline SOURCE & DATA ACCESSED & LOCATION & $\begin{array}{l}\text { TIME } \\
\text { SPAN }\end{array}$ \\
\hline Commercial shrimp trap logs & $\begin{array}{l}\text { catch weight, location, depth, } \\
\text { no. traps, date fished }\end{array}$ & MARFIS & 1995-2005 \\
\hline Commercial shrimp trawl logs & $\begin{array}{l}\text { catch weight, location, depth, } \\
\text { hours, date fished }\end{array}$ & MARFIS & 1993-2006 \\
\hline $\begin{array}{l}\text { Commercial (trap and trawl) } \\
\text { and trawl survey catch samples }\end{array}$ & $\begin{array}{l}\text { carapace length, indiv. weight, } \\
\text { sex, life history stage }\end{array}$ & VDC & 1995-2006 \\
\hline $\begin{array}{l}\text { DFO-industry shrimp trawl } \\
\text { survey }\end{array}$ & $\begin{array}{l}\text { shrimp catch weight, location } \\
\text { bottom temperature }\end{array}$ & & \\
\hline DFO groundfish trawl survey & $\begin{array}{l}\text { shrimp catch weight, location } \\
\text { bottom temperature }\end{array}$ & VDC & 1999-2006 \\
\hline DFO-industry crab trawl survey & shrimp catch weight, location & VDC & 2003-2005 \\
\hline
\end{tabular}

Detailed information on the biological characteristics of shrimp sampled ( 500 shrimp/sample) during all trapping and trawling operations (survey, experimental and commercial fishing) included: carapace lengths to the nearest $0.1 \mathrm{~mm}$, individual weight to the nearest $0.01 \mathrm{gm}$, sex and reproductive development stage. The latter included identification of individuals as transitional (in the process of changing sex from male to female), primiparous females (about to spawn for the first time), multiparous females (spawned at least once before) and ovigerous females (eggs on the abdomen). Primiparous and multiparous females are distinguished by the presence or absence of sternal spines, which are lost on first spawning.

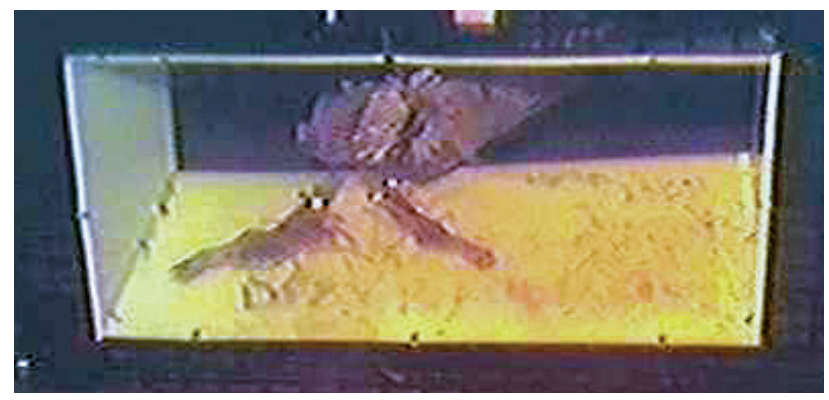

Fig 2. Video grab from footage taken aboard the DND submersible SDL-1 in 1996, in the Louisbourg Hole east of Cape Breton Island (depth 200m). Two shrimp are inspecting one end of the bait bag protruding from the entrance. Both shrimp subsequently worked their way along the bait bag into the trap. The taper of the entrance flanges prevents escape. Note that this trap was placed on its side for observation. purposes. 
Samples were collected bi-weekly during experimental trapping, less frequently ( monthly) during commercial trapping. They are collected from all survey catches and from a temporally and spatially representative portion of the trawl fishery. Shrimp stage length statistics were calculated as described in Koeller (2006).

Surficial geology charts published by the Geological Survey of Canada, Department of Energy, Mines and Resources were used to characterize the ocean bottom on the Scotian Shelf and Bay of Fundy, particularly the location of the muddy clay preferred by P. borealis (e.g. Fader 1991).

\section{RESULTS AND DISCUSSION}

\section{Shrimp trapping and distribution of the resource}

Figure 3 plots successful shrimp catches from experimental and commercial shrimp trap logbooks (green circles, 1995-2005), and from DFO groundfish surveys (blue circles, 1999-2006). This figure also shows the location of null trap (red circles) and trawl (open blue circles) sets (i.e. zero shrimp catches) and so can be used to determine the overall distribution of shrimp concentrations on the Scotian Shelf and Bay of Fundy, as well as the locations where shrimp were trapped successfully. Most notable are the large commercially fished (by trawlers) concentrations of shrimp on the eastern Scotian Shelf. These are found both in the deep (>200m) offshore shrimp holes (e.g. Whitehead, Misaine and Louisbourg, Fig 3) and

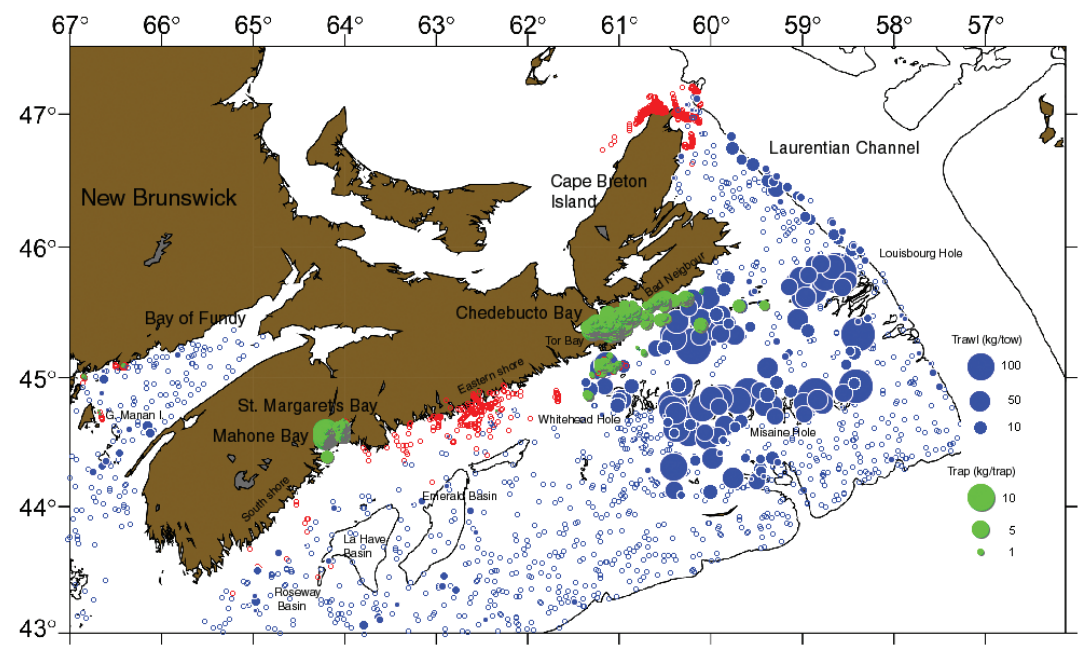

Fig 3. Cumulative catches of Pandalus from experimental and commercial shrimp trap logbooks (1995-2005, solid green circles), and DFO groundfish surveys (1999-2006 solid blue circles). Locations where no shrimp were caught are shown as open circles (trap - red, trawl - blue). Note that along the eastern and south shores southwest of Tor Bay groundfish surveys do not cover the nearshore (inside the $\sim 100 \mathrm{~m}$ depth contour) and so are indicative only of offshore shrimp distribution. 
an inshore area, known as the "Bad Neighbour" (after a shoal of the same name), running from Chedabucto Bay north-eastward along the shore of Cape Breton Island. This latter area has good "muddy" shrimp bottom habitat, geologically termed La Have clay (Fader 1991), which extends some distance offshore, but is separated from the muddy offshore holes to the south and east by shallower water and harder sandy-gravel bottom (Fig 4). The continuity of shrimp catches by trappers in Chedabucto Bay

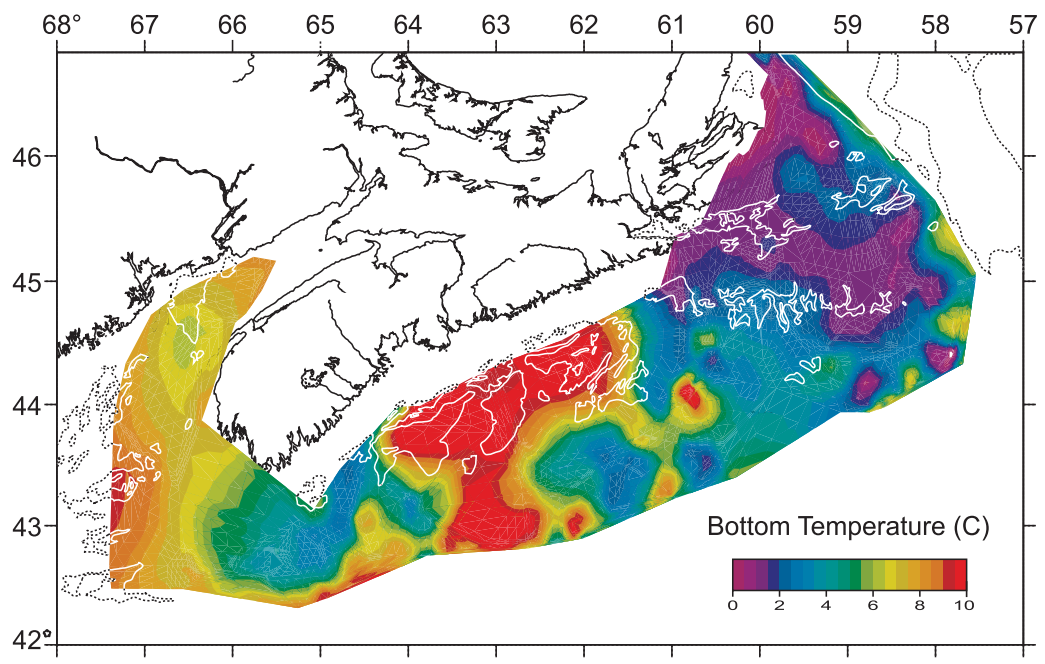

Fig 4. The Scotian Shelf and Bay of Fundy showing the typical large scale distribution of bottom temperatures (e.g. July 1996 groundfish survey), and the distribution of the best shrimp habitat (La Have clay, areas enclosed by white and dotted black lines).

and trawlers in the Bad Neighbour and the continuity of habitat (Figs 3, 4) indicate that the shrimp in these two areas are likely a single population. The relationship between Bad Neighbour shrimp and those in the offshore holes is less clear since the Bad Neighbour and offshore populations are separated by shallower, harder bottom (Fig 4), and both survey and commercial catches (Fig 3) are discontinuous. However, shrimp do move into shallower water during fall-winter (Koeller 2000). This, together with the similarity of their biological characteristics in all areas on the eastern Scotian Shelf (Koeller et al. 2006), suggests that they also constitute a single population. In any case, the success of the trap fishery in Chedabucto Bay appears to be due, at least in part, to the availability of shrimp from the large, adjacent concentration in the Bad Neighbour area.

Figure 5 combines cumulative catch locations from commercial trappers (green stippling) and trawlers (yellow stippling), shrimp catches from shrimp, crab and groundfish surveys (red circles), and the location of the preferred soft mud habitat (light blue shading). Most shrimp trapping occurs at the mouth of Chedabucto Bay at about $100 \mathrm{~m}$, over two patches of mud, one 


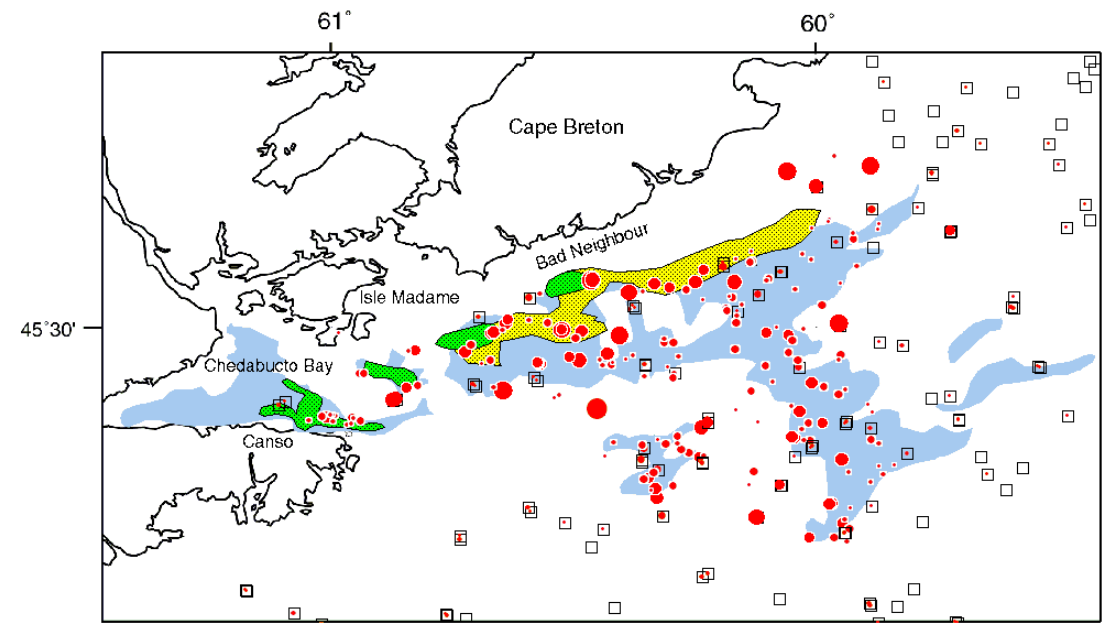

Fig 5. Areas where commercial shrimp trapping (green shading) and trawling (yellow shading) are conducted in Chedabucto Bay and the Bad Neighbour, from log book data. Also shown are cumulative catches of DFO-industry shrimp surveys in June (1995-2006), DFO-industry crab surveys in fall (2004-2005) and DFO groundfish surveys in July (1999-2006) in relative numbers (red circles). Larger circles indicate larger catches, open squares indicate null catches. Shrimp habitat (La Have clay) is shown in light blue.

directly off Canso, the other southeast of Isle Madam. Some trapping also occurs outside the Bay along the Cape Breton shore at the northern edge of the La Have clay, where most of the inshore trawling is conducted. Survey catches show, however, that relatively large quantities of shrimp are found over the soft bottom throughout the Bad Neighbour area, not just in the area nearest to shore where all of the trapping and most of the trawling is conducted. In addition to the extensive shrimp habitat found both inshore and offshore on the eastern Scotian Shelf, temperatures throughout the area are cold compared to the rest of the shelf and within the global preferred range $\left(1-6^{\circ} \mathrm{C}\right)$ of $P$. borealis (Shumway et al. 1985, Fig 4).

The situation is rather different in the area between St. Margaret's Bay and Chedabucto Bay known as the eastern shore (Fig 3). Good shrimp bottom is plentiful in the deep water $(>100 \mathrm{~m})$ offshore (i.e. in Emerald, La Have Basins), but the water temperatures over these areas are generally above the preferred range (Fig 4). As a result, shrimp are rarely found in these basins. Most of the small embayments along the eastern shore also have fine mud bottoms, but they are quite shallow $(<40 \mathrm{~m}$, Table 2$)$ and the mud is usually restricted to the bays themselves. Even if shrimp were present offshore, they would be separated from the eastern shore bays by a wide $(\sim 20-50 \mathrm{~km})$ strip of harder bottom which runs near shore along mainland Nova Scotia (Fig 4). Trapping along the eastern shore has generally been unsuccessful (red circles, Fig 3 ), probably because of the 
Table 2 Depths of major embayments along the coast of Nova Scotia arranged northeast to southwest. Depths where most trap fishing is conducted are also given.

\begin{tabular}{llcc}
\hline & & $\begin{array}{c}\text { Maximum } \\
\text { Depth }(\mathbf{m})\end{array}$ & $\begin{array}{c}\text { Fishing } \\
\text { Depth }(\mathbf{m})\end{array}$ \\
\hline \multirow{5}{*}{ Eastern Shore } & $\begin{array}{l}\text { Chedabucto Bay } \\
\text { Tor Bay }\end{array}$ & 183 & $100-150$ \\
& Country Harbour & 40 & \\
Indian Harbour & 37 & \\
Sheet Harbour & 31 & \\
Ship Harbour & 26 & \\
Jeddore Harbour & 18 & \\
Chezzetcook Inlet & 33 & \\
Bedford Basin & 5 & \\
St. Margaret's Bay & 70 & \\
& Mahone Bay & 84 & \\
& Medway Harbour & 59 & \\
Liverpool Bay & 18 & \\
Port Mouton & 27 & \\
South Shore & Port Joli & 40 & \\
& Lockport Harbour & 20 & \\
Jordan Bay & 15 & \\
Shelbourne Harbour & 33 & \\
Barrington Bay & 26 & \\
Bay of Fundy & 20 & \\
& & 223 & \\
\hline
\end{tabular}

limited amount of suitable habitat in the small embayments, and the lack of an adjacent "feeder" population. However, one experimental trapper successfully caught shrimp at the north-eastern limit of the eastern shore, 10-15 km off Tor Bay, at the northern edge of the Whitehead Hole (Fig 3). This is the closest distance between any of the offshore shrimp holes and the Nova Scotia mainland and is relatively accessible to the small lobster boats used to trap shrimp. It is noteworthy that shrimp were not caught in Tor Bay itself, presumably because they did not cross the harder bottom between it and Whitehead Hole.

Farther to the southwest the situation is different again. Shrimp are trapped successfully in Mahone and St. Margaret's Bays, but there are no large adjacent or offshore populations as in Chedabucto Bay. It is noteworthy, however, that small quantities of shrimp were found offshore in groundfish trawl survey catches, mainly in the Roseway Basin area where the shrimp trawl fishery occurred during the early 1970s (Fig 3). In addition to having La Have clay habitat, Roseway Basin also has the coolest water on the western Scotian Shelf (Fig 4), although it is only marginally within the preferred temperature range, and not during all years (Koeller 2000). The small survey trawl catches offshore are probably remnants of the commercially exploited population which had developed during a more environmentally favourable time period i.e. the colder water temperatures of the mid-to late 1960s (Koeller 2000). It is possible that the shrimp trapped in Mahone and 
St. Margaret's Bays also originate from this relic offshore population. As in Chedabucto Bay, the best shrimp trapping occurs in winter (see below under temporal trends). Trap catches tend to increase in the fall, decrease in the spring and are usually poor in the summer, suggesting that shrimp move into these bays during fall-winter, and out of them in the springsummer, similar to the inshore-offshore migrations reported for the Gulf of Maine population (Shumway et al. 1985, Schick 1982). In the Mahone-St. Margaret's Bay area the small quantities of shrimp found offshore, as well as their long distance $(\sim 40 \mathrm{~km})$ from the inshore bays across hard bottom, makes it likely that the seasonal pattern of trap catches here results from relatively short distance movements of a local stock. The shrimp habitat within Mahone and St. Margaret's Bays is somewhat shallower $(50-70 \mathrm{~m})$ than Chedabucto Bay (100-150m), but considerably deeper than the smaller amounts of muddy bottom found in the small bays and harbours along the eastern and south shores which are generally shallower than $40 \mathrm{~m}$ (Table 2). In terms of shrimp trapping success, Mahone, St. Margaret's and Chedabucto Bays stand out as being both the largest and deepest embayments along the outer coast of Nova Scotia. It is noteworthy that shrimp trapping has not been attempted in Bedford Basin. Situated near Mahone and St. Margaret's Bays, it has similar depth and habitat characteristics, which may be suitable for a local population of $P$. borealis.

Unsuccessful experimental trapping along the south shore southwest of Mahone Bay suggests that this area is similar to the eastern shore, although the amount of trapping attempted here is limited. A fisher from the southwestern end of the area licensed to fish the entire south shore including Mahone Bay continues to station his boat in the Bay during winter for the shrimp fishing because shrimp are unavailable closer to his home port. In the Bay of Fundy, limited experimental trapping yielded a few shrimp, but not in commercial quantities. These shrimp may have come from the relic population, delineated by a few small catches from groundfish surveys, fished commercially during the late 1960s (Fig 3, Koeller 2000). Except for the presence of a large shrimp population and suitably cold water, conditions here seem ideal for inshore shrimp trapping, with good quantities of mud bottom in deep $(\sim 180 \mathrm{~m})$ water adjacent to the shore of Grand Manan Island. This area may produce a trap fishery in the future, if temperatures decline and a large population develops again.

Extensive experimental trapping off northern Cape Breton failed to catch any shrimp although groundfish surveys show their presence in small numbers relatively close by, along the south-western edge of the Laurentian Channel (Fig 3). Experimental trawling by the fishing industry has also failed to find commercial quantities in the area (Koeller, unpublished data). Although the bottom type is suitable in the Laurentian Channel, temperatures are at or above the upper limit of the preferred range $\left(6^{\circ} \mathrm{C}\right)$. The sea bottom at the experimental trapping sites is notably harder, consisting mostly of sand and gravel. In addition, the coast is relatively open, lacks major deeper embayments, and is subject to strong currents which make trapping more difficult, as evidenced by frequently overturned and displaced traps. 


\section{Temporal patterns in the trap fishery}

The permanent trap fisheries in Chedabucto and Mahone Bays, as well as the experimental fishery in St. Margaret's Bay, are essentially winter fisheries. Chedabucto Bay has tended to have the longest season, extending from late summer-fall to spring, with sharp increases and decreases in catch rates at the beginning and end of the season (Fig 6). The timing
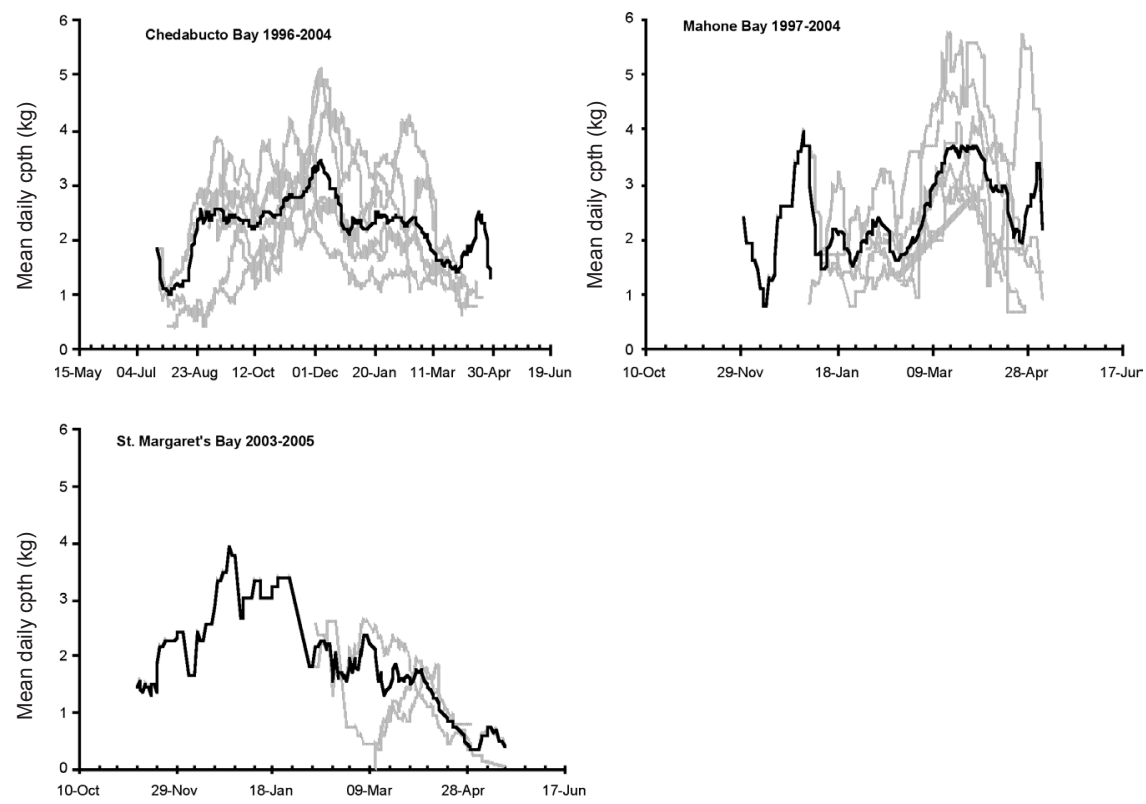

Fig 6. Filtered (9d running mean) daily mean shrimp catch per trap haul from Chedabucto, Mahone and St. Margaret's Bays for the years shown. Shaded lines: daily mean for individual years (not identified by year); solid lines: daily means, all years.

of the increase in catch rates in Chedabucto Bay at the beginning of the season has varied - it has occurred as early as July-August in some years, and not until September in others. Catch rates fluctuated at relatively high levels throughout the season, but there appears to be a decline beginning in December to low levels by the end of April during most years. The pattern appears similar in St. Margaret's Bay, although only limited data are available. The seasonal pattern in Mahone Bay is somewhat different, with a slower increase during most years after the New Year, peak catch rates in March, followed by a relatively rapid decline to the end of April. The seasonality of these patterns could be related to environmental factors, particularly temperatures, which have been shown to influence shrimp abundance and movements (Shumway et al. 1985, Stein 2000).

The seasonal temperature cycles at various depths and locations in Nova Scotia, including temperatures from trap-mounted recorders during 

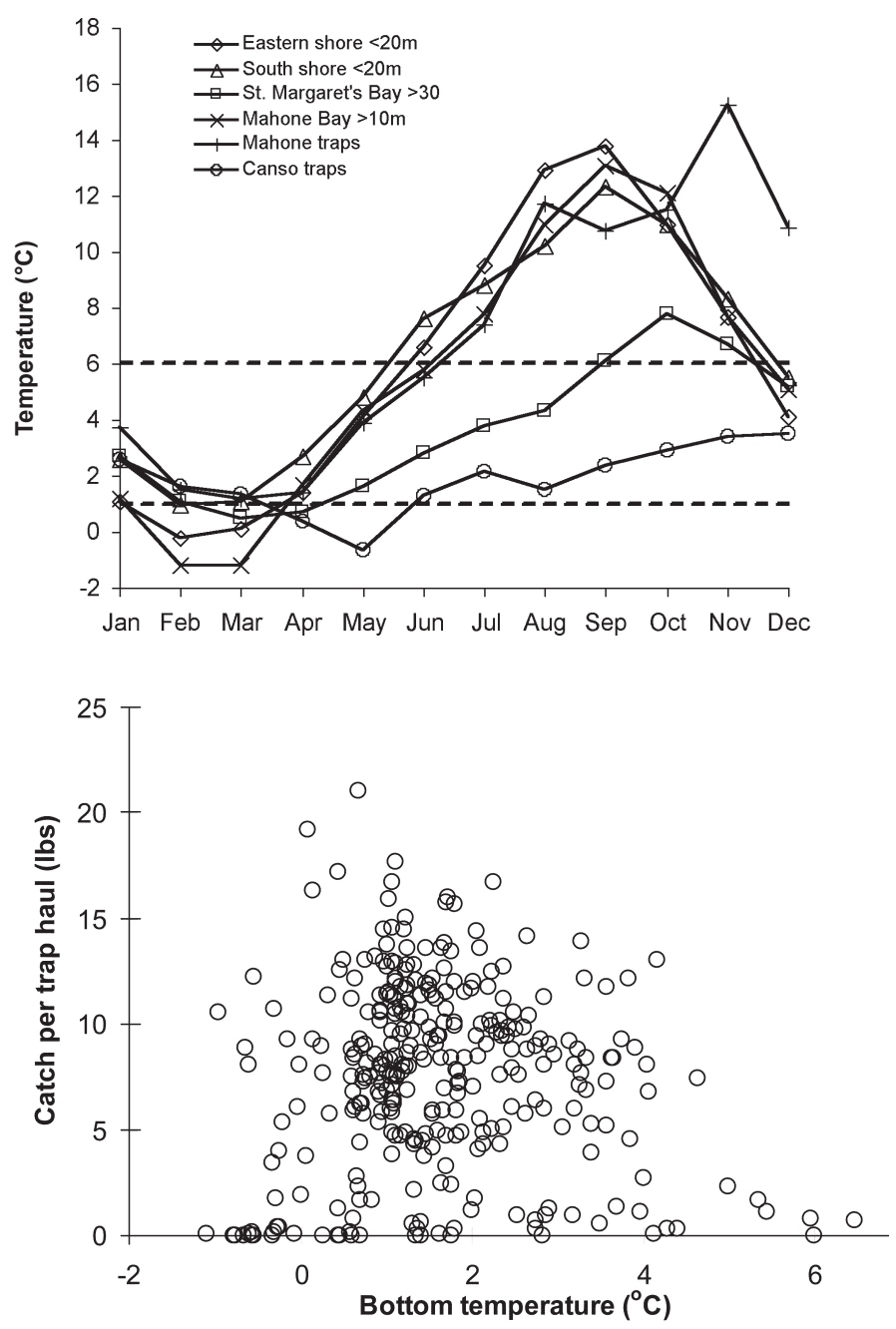

Fig 7. Upper - seasonal temperature $\left({ }^{\circ} \mathrm{C}\right)$ cycle for various areas of interest on the Scotian Shelf. The data were obtained as monthly averages across years at specific depth ranges from the DFO coastal oceanographic database (Gregory 2004) or from continuous temperature recorders attached to shrimp trap during fishing operations. The preferred temperature range of $P$. borealis is also shown (dashed lines). Lower - daily mean catches per trap haul versus daily mean bottom temperatures where both data types were available in Chedabucto Bay 1994-1997.

the fishing season, are shown in Fig 7 (upper), along with the preferred (global) temperature range of $P$. borealis. Available seasonal data along the eastern and south shores are mainly from depths shallower than $20 \mathrm{~m}$, however most of the embayments in these areas are this shallow and the temperatures shown are probably representative of the bottom habitat within 
most of them. Temperatures along the south and eastern shores fall within the preferred temperature range of $P$. borealis for only 3-4 months of the year (mainly April-June). Temperatures are at or above the lower end of the preferred range in late winter (January-March), and at or above the upper end from summer to early winter (June-December). Combined with limited availability of mud habitat and absence of an offshore feeder population, this may contribute to the apparent lack of shrimp in these areas.

In contrast, the trapping grounds in Chedabucto Bay have temperatures within the preferred range for 9-10 months of the year, from summer to winter (July-February). In addition, extensive favourable habitat and feeder populations are found immediately outside the Bay and farther offshore. The combination of these three factors probably contributes to the success of trapping operations close to Canso. Water temperatures off Canso are generally in the lower half and often near the lower limit of the preferred range. The decrease in shrimp catch rates here begins in DecemberJanuary when temperatures also begin to decrease. Shrimp catch rates reach their lowest values when water temperatures on the shrimp grounds decrease below the preferred range in April. A plot of catch rates versus bottom temperatures (Fig 7, lower) shows that catch rates decline rapidly below $1^{\circ} \mathrm{C}$ as expected from the known preferred temperature range. While these data suggest that the appearance and disappearance of shrimp in the Chedabucto Bay trap fishery is related to the seasonal water temperature cycle, it is not clear if this is due to a seasonal migration into and out of the trapping area or to lower activity as shown for lobsters (McCleese \& Wilder 1958, Koeller 1999). However, the seasonal cycle of trap catches in Chedabucto Bay and commercial trawling in the Bad Neighbour outside it (Fig 8), as well as survey catches within and immediately outside the Bay

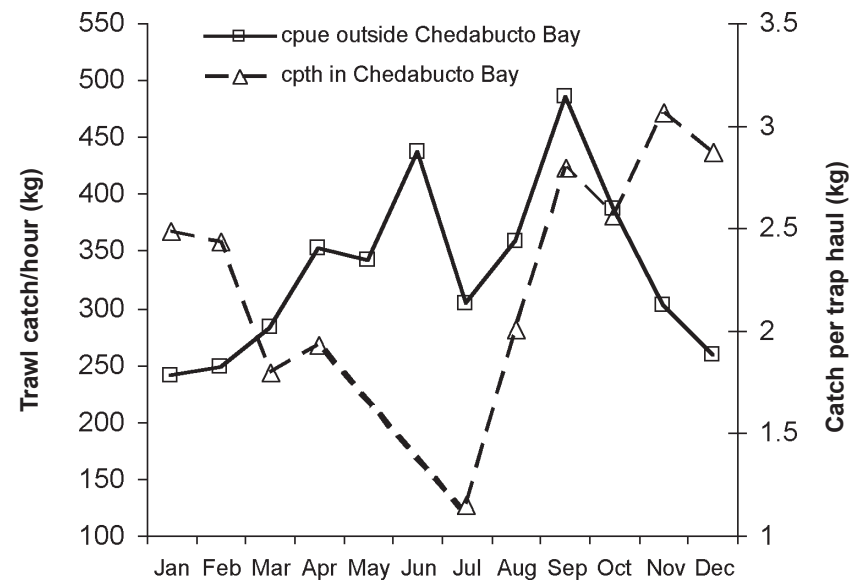

Fig 8. Mean monthly catch per trap haul by shrimp trappers inside Chedabucto Bay (19962004) and mean monthly catch per hour by trawlers outside Chedabucto Bay in the Bad Neighbour area. 
in June when trap catches in the Bay are usually at their lowest (Koeller et al. 2006), supports a migration from the Bay into the Bad Neighbour in spring, and vice versa in fall.

The seasonal pattern of catch rates and temperatures in St. Margaret's Bay is similar to Chedabucto Bay (Figs 6,7), however, because water is shallower in St. Margaret's Bay, temperatures are more strongly influenced by seasonal heating and tend to be warmer. They are also outside the preferred range for 1-2 months longer than in Chedabucto Bay, and above the preferred range in fall (September-November), which may account for the later start to the fishery in St. Margaret's Bay relative to Chedabucto Bay. Catches decrease in the late winter-spring (February-April) when temperatures dip below the preferred range. The lack of catches during the spring-fall (May-September) period when temperatures are mainly within the preferred range is due to the lack of effort during this period when fishers are otherwise engaged (e.g. the lobster fishery) - shrimp may be present in the Bay and trappable during this period but there are no data to support this.

Mahone Bay is shallower yet than St. Margaret's Bay (Table 2) with depths near or outside those influenced by the previous winter's cold water and strongly influenced by seasonal heating. Consequently, its seasonal temperature profile is similar to the eastern and south shore (Fig 7, upper), with preferred temperatures occurring during short periods in winter (December-January) and spring (April-June). This may partially account for the different pattern of catch rates, including a winter increase that is later than St. Margaret's Bay as temperatures decrease into the preferred range, followed immediately by a decrease in catch rates as temperatures dip below it. As in St. Margaret's Bay, the lack of catches during the period of favourable temperatures during the warming period (April-June) are due to lack of effort while fishers are otherwise engaged and not necessarily to the absence of shrimp.

Daily catch per trap haul data in all areas (Fig 6) show shorter term changes in addition to the seasonal cycles. For example, in Chedebucto Bay during the 1996-1997 season, in addition to the increasing trend throughout the season, the unsmoothed data (Fig 9A) as well as the same data smoothed with a 28-day moving average (Fig 9B), show three peaks in catch rates. This suggests that three "waves" of shrimp entered the Bay during this fishing season. The percentage of females in the catch that were carrying eggs followed the same short term cycles suggesting that these waves were mainly comprised of ovigerous females, a situation analogous to the Gulf of Maine where ovigerous females are reported to migrate inshore during winter to release their eggs (Schick 1982). Spawning (egg extrusion onto the abdomen) occurs only once a year during late summer on the Scotian Shelf (Koeller 1995, 1996a) with hatching in late-winter/spring (March-April), so these waves are not due to spawning events, but rather to a periodic immigration of ovigerous females entering the Bay, or to changes in their catchability. 

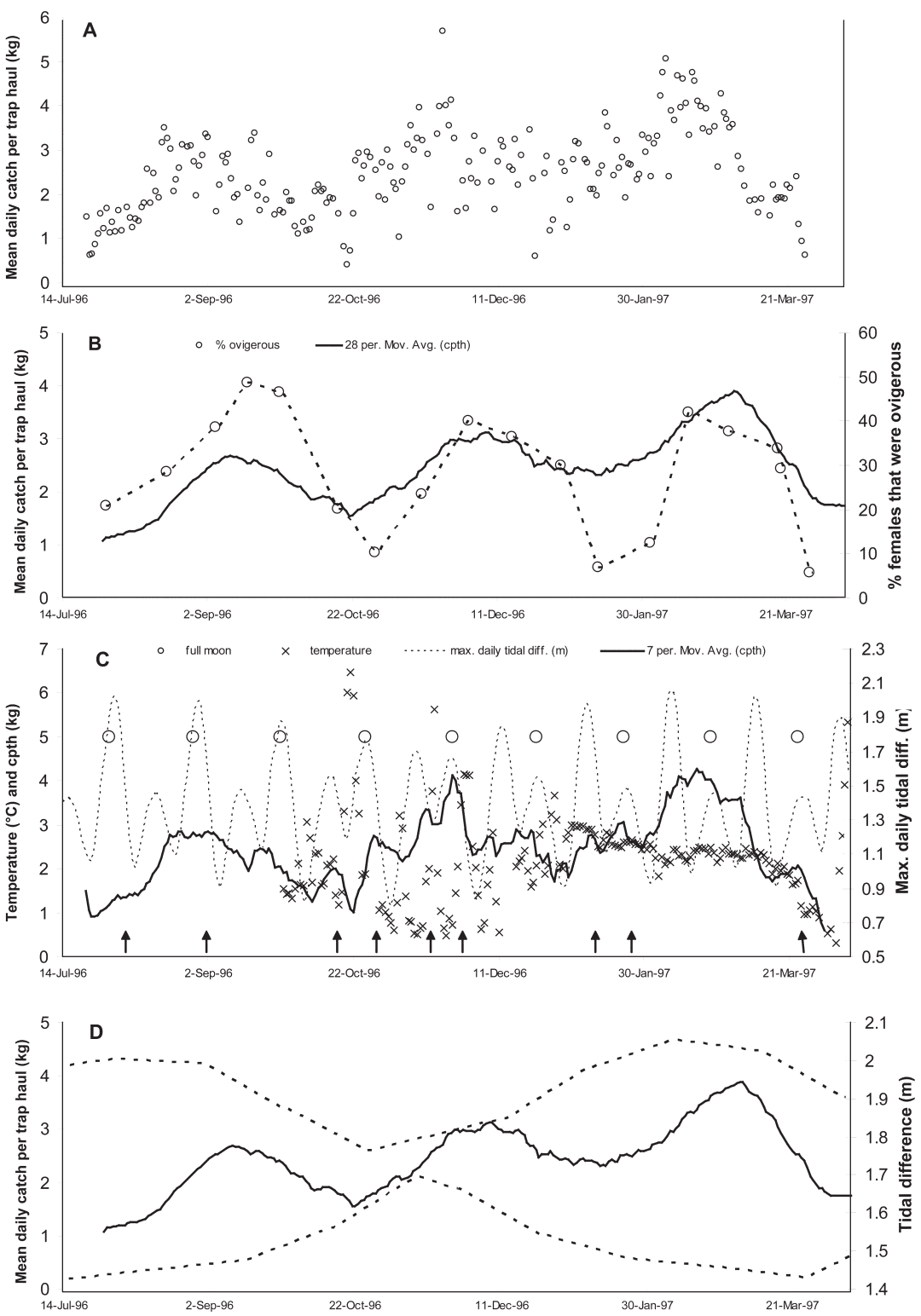

Fig 9. Mean daily catch per trap haul for the 1996-1997 shrimp fishing season in Chedabucto Bay including $A$. the raw daily means, $B$. the same data smoothed with a $28 \mathrm{~d}$ moving average along with the percent of females which were ovigerous in the trap catches (bi-weekly samples), C. Same catch data as above smoothed with a 7-day moving average. Also shown in this panel are mean daily bottom temperatures on the shrimp grounds, the time of the full moon and the tidal cycle, and D. Lower frequency tidal cycle outlined by monthly high-high (upper dashed line) and high-low (lower dashed line) water and the smoothed daily catch per trap haul. 
A higher frequency periodicity is also apparent in the same data set when it is smoothed with a seven day moving average (Fig 9C). Some shrimp fishers have indicated that trap catches are related to the lunar cycle, so this figure also shows the time of the full moon and the predicted tidal cycle during the period. Trawl catches of $P$. borealis have been strongly correlated with tidal cycles (Parsons \& Sandeman 1981). The higher frequency periodicity does appear to be related to the tidal cycle for at least part of the fishing season, with many of the peaks in catch rates coinciding with tidal peaks. In addition it is known that shrimp orient themselves along currents facing downstream. Observations and underwater photography of Ivanov (1999) and Koeller (1996b) indicate that shrimp behaviour is strongly influenced by water currents including tides. Shrimp are known to undergo diurnal vertical migrations, which will displace them horizontally during the tidal cycle. The amount of this displacement will be proportional to the tidal range, provided that behaviour is otherwise passive. Appropriate modification of diurnal migratory behaviour, such as remaining on the bottom during the ebb, would result in net displacement and increase of the population in an area such as Chedabucto Bay. However, immigration into the Bay is not required to explain the periodic increases in trap catches. During greater tidal ranges more water is transported past any given point such as a trap and more shrimp will come in contact with it and be caught no matter what direction the water is moving. It is also then possible that the lower frequency cycles in trap catch rates (Fig 9A, B) are associated with lower frequency tidal oscillations as suggested by Fig 9D. Water temperatures did not appear to be strongly related to either the high or low frequency changes in catch rates during this fishing season (Fig 9C) although they did appeared to be associated with the drop in catch rates at the end. Note that the large fluctuations in temperatures during the fall-winter period were probably due to storm mixing of a stratified water column. The influence of lunar, tidal and diurnal cycles on the physiology, behaviour, abundance, migrations and catches of marine organisms is a common phenomenon and has been documented for many species, including shrimp (e.g. Parsons \& Sandeman 1981, Subramanyam 1965).

\section{Stock relationships and growth of trapped shrimp}

The relationship between the length at sex transition $\left(L_{t}\right.$, the length at which males change to females) and the maximum size achieved $\left(L_{\max }\right)$ has been used to define northern shrimp populations (Skúladóttir \& Pétursson 1999). Figure 10 shows that $L_{t}$ and $L_{\max }$ from samples collected in the Gulf of Maine and the Scotian Shelf, including the offshore holes, Bad Neighbour, and Mahone-St. Margaret's Bays, adhere to the invariance rule demonstrated for this species throughout its wide range (Charnov \& Skúladóttir 2000, Koeller 2006) i.e. the slope of the regression line, or the ratio of the two variables of a sufficient number of samples, approximates 0.8 (the mean ratio of $L_{t}$ to $L_{\max }$ in the figure $=0.78$ ). Both the Mahone Bay and St. Margaret's Bay samples have $L_{t}$ and $L_{\max }$ values which are significantly shorter $(p<0.0001)$ 


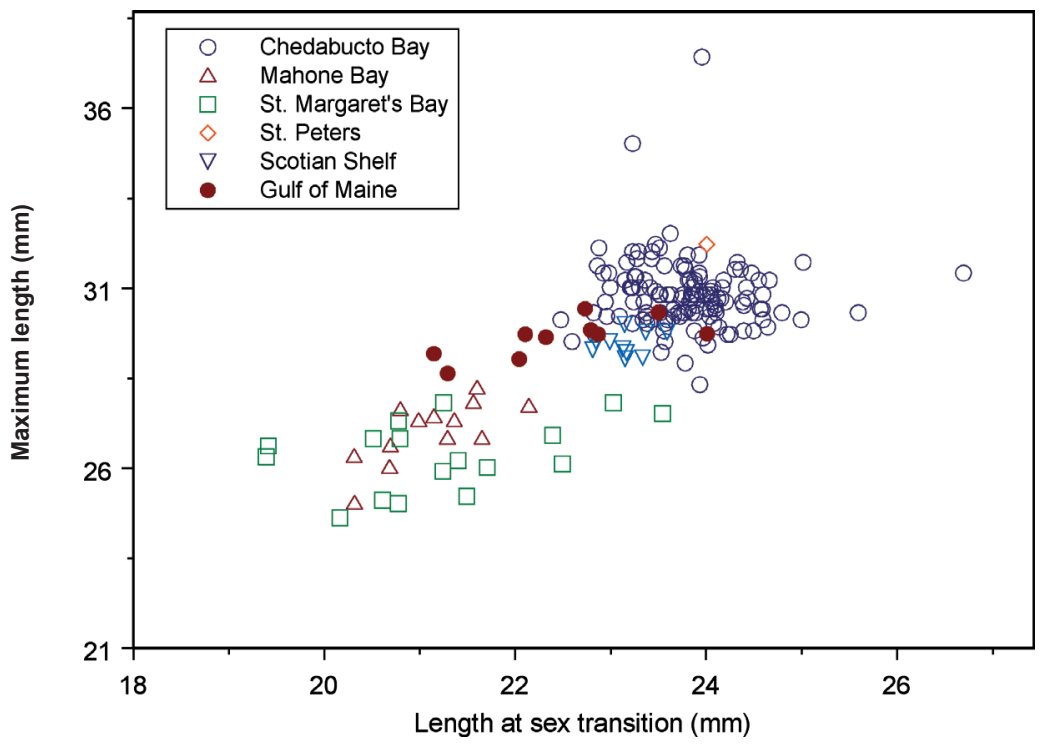

Fig 10. Carapace length at sex transition $\left(L_{t}\right)$ versus maximum size $\left(L_{\max }\right)$ for individual samples collected by trap in the defined areas. The values for the Scotian Shelf and Gulf of Maine represent annual averages of between 40 and 60 samples collected by research survey trawls. The mean ratio of $\mathrm{L}_{\mathrm{t}} / \mathrm{L}_{\max }$ of these samples and annual averages is 0.78 . The single sample marked St. Peter's comes from the north shore of the Chedabucto Bay, samples marked Chedabucto Bay are from the south shore near Canso.

than the shrimp trapped in Chedabucto Bay or trawled on the eastern Scotian Shelf, indicating that they have significantly different growth characteristics (Koeller 2006). In addition to their distance from the shrimp concentrations on the eastern Scotian Shelf and lack of distributional continuity between them, this strongly suggests that the shrimp trapped in Mahone Bay and St. Margaret's Bay constitute a separate population. The $L_{t}$ and $L_{\max }$ values from Mahone Bay are not significantly different from those in St. Margaret's Bay, consequently shrimp trapped in these bays may come from the same local population. Shrimp trapped in Chedabucto Bay, although significantly larger than trawled shrimp on the eastern Scotian Shelf, are closer in size to the latter than any other area. The continuity of shrimp sizes in Chedabucto Bay with those in the Bad Neighbour, which in turn are not significantly different in $L_{t}$ and $L_{\text {max }}$ from the offshore holes, suggests that the shrimp in trapped samples are larger than the trawled shrimp due to selectivity differences between the two gear types, not to differences in growth. They probably belong to the same population managed as a single stock on the eastern Scotian Shelf.

An analysis of all life history stage lengths arranged chronologically (the "stage structure") can be used to infer growth characteristics (Koeller 2006), although this is more difficult if the stage structure is influenced by selectiv- 


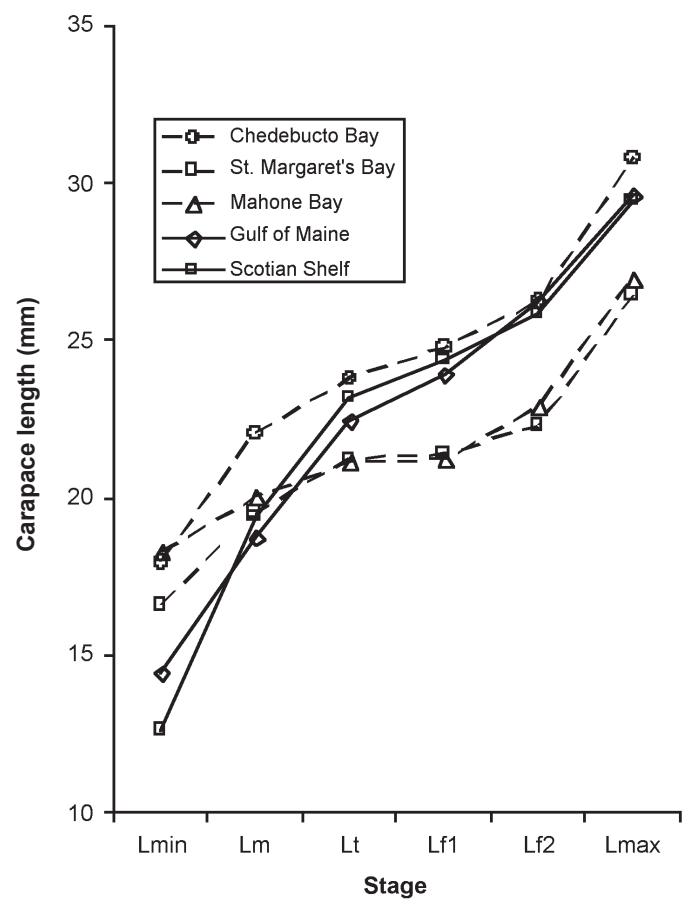

Fig 11. Stage structure for shrimp populations from samples collected by traps (dashed) and research survey trawls from the areas identified. The stage carapace lengths are for $L_{\min }$ - mean minimum length in the group of samples, $L_{m}$ - mean size of males, $L_{t}$ - mean length at sex change, $L_{f 1}$ - mean length of primiparous females, $L_{f 2}$ mean length of multiparous females and $L_{\max }$ - mean maximum length in the group of samples.

ity factors. However, since all shrimp trapping fisheries require the same trap type and construction under license conditions, comparisons between trapped samples should be valid, as should comparisons between trawl and trapped samples for larger sizes where selectivity for both gear types is near $100 \%$. Figure 11 gives mean stage sizes for trap samples and survey samples from the Scotian Shelf and Gulf of Maine collected over a number of years. The similarity between all stage lengths in Mahone Bay and St. Margaret's Bay, except for the minimum size of shrimp in each sample $\left(\mathrm{L}_{\min }\right)$, further supports the hypothesis that these shrimp come from the same population. The Chedabucto Bay trap sample stage lengths are generally larger than stage lengths from trawl samples on the eastern Scotian Shelf, however, the difference between these areas are greater at the smaller stages and tend to decrease with stage size, supporting the view that the differences are mainly due to differences in selectivity between shrimp traps and trawls. The opposite is the case for trap samples in Chedabucto Bay versus Mahone and St. Margaret's Bays. Most life history stages are clearly larger in Chedabucto Bay trap samples, but the difference between areas 
is less for the smaller stages. The generally larger sizes of shrimp stages in Chedabucto Bay trap samples relative to Mahone and St. Margaret's Bays could be due to slower or faster growth, depending on how many male year classes are present. Usually when shrimp grow slower, they spend more time in the male stage, resulting in an additional year(s) of growth and a larger size at transition and subsequent stages. However, in the productive Gulf of Maine the combination of faster metabolic rates due to warmer water temperatures combined with sufficient food availability, results in exceptionally high growth rates and shrimp that are as large as those on the Scotian Shelf which grow much slower (Fig 11, Koeller 2006). This is clearly not the case for shrimp in the Mahone-St. Margaret's area. Except for the smallest stages $\left(\mathrm{L}_{\min }\right.$ and $\mathrm{L}_{\mathrm{m}}$ ) whose sizes are influenced by selectivity differences between gears, all stages in Mahone-St. Margaret's Bay area are smaller than either the Gulf of Maine trawl or the eastern Scotian Shelf trap and trawl samples. For the comparable trapped samples, all stages from St. Margaret's Bay and all but $L_{\text {min }}$ from Chedabucto Bay are smaller than trap samples from Chedabucto Bay. It seems likely that these smaller stage sizes result from growth rates that are slower than all other areas throughout their life history. This is plausible considering the variable and marginal conditions experienced by a small inshore population. Unfortunately, the first and second year modes which can be used to determine actual growth rates in the first two years of life are usually not distinguishable in trap samples due to selectivity against smaller shrimp, so this hypothesis cannot be confirmed with the material at hand.

In summary, despite a significant amount of experimental trapping over several years along much of the Nova Scotia coast, in only two areas have permanent trap fisheries been developed - Chedabucto Bay and Mahone Bay - note that the fishery in St. Margaret's Bay was still experimental at the time of writing but also appears to be sustainable. The impression is that successful shrimp trapping along the coast of Nova Scotia by small $(\sim 10 \mathrm{~m})$ vessels is limited to a few areas with the appropriate combination of physical and biological attributes close to shore. On the eastern Scotian Shelf the availability of suitable habitat, including cold deep water and mud bottom, has allowed the establishment of commercially exploitable, permanent populations both offshore and inshore. Inshore, the shrimp habitat of the Bad Neighbour extends well into Chedabucto Bay and within a mile of Canso, as well as along the shore of Cape Breton. This has allowed small vessels to trap shrimp year round, particularly in winter when catch rates are the highest, probably due to inshore migration of larger, especially ovigerous, shrimp as occurs in Maine. There are currently no major populations offshore from Mahone Bay and St. Margaret's Bay, although these did exist in the past when environmental conditions were more favourable. It is unlikely that the shrimp which appear in these bays during winter originate from this remnant offshore population, since this would entail a lengthy migration over relatively hard bottom. We hypothesise that these shrimp constitute a local population which, driven by the annual temperature cycle, moves into and 
out of the inner bay areas where most of the trapping occurs. Mahone and St. Margaret's Bays are generally deeper and much larger in area than the embayments of the eastern and south shores - their extensive mud habitat are more likely to harbour local populations of $P$. borealis.

Acknowledgements. The authors wish to thank the numerous shrimp trap and trawl fishermen who provided the catch and effort information and the shrimp samples analysed in this paper. We also thank Charles O'Reilly for providing the tidal data, and Brian Petrie for advice on access, use and interpretation of hydrographic data. Dr. J. Choi kindly provided crab survey data. Three anonymous reviewers and Dr. James E. Stewart provided helpful comments which significantly improved the manuscript.

\section{REFERENCES}

Charnov E, Skúladóttir U (2000) Dimensionless invariants for the optimal size (age) of sex change. Evol Ecol Res 2:1067-1071

Fader GBJ (1991) Surficial geology and physical properties 5: surficial geology. In: East Coast Basin Atlas Series, Scotian Shelf. Atlantic Geosciences Centre, Geological Survey of Canada, Dartmouth, NS

Gregory DN (2004) Coastal Time Series (CTS): ADatabase of Coastal Temperature Time Series for the Canadian East Coast DFO. Can Sci Advis Sec Res Doc 2004/096

Halliday RG, Koeller PA (1981) A History of Canadian groundfish trawling surveys and data usage in ICNAF Divisions 4TVWX. In: Doubleday WG, Rivard D (eds) Bottom Trawl Surveys. Can Spec Publ Fish Aquat Sci 58

Hunter C, Koeller P (1997) A database for research survey and commercial fishery data on Scotian Shelf shrimp (Pandalus borealis). Can Man Rep Fish Aquat Sci 2410

Ivanov B (1999) (VNIRO, V.-Krasnoselskaja 17, Moscow B-140, 107140) Personal communication

Koeller P (1995) Results of the experimental shrimp trap fishery in 1995. DFO (Department of Fisheries \& Oceans) Atlantic Fisheries Research Document $96 / 10$

Koeller P (1996a) Aspects of the biology of northern shrimp Pandalus borealis on the Scotian Shelf. DFO (Department of Fisheries \& Oceans) Atlantic Fisheries Research Document 96/9

Koeller P (1996b) (Bedford Institute of Oceanography, Dartmouth) Unpublished video footage taken from Department of National Defence submersible SDL-1, dives 1071-1075, 1996

Koeller P (1999) Influence of temperature and effort changes on lobster catches at different temporal and spatial scales and its implications for stock assessments. Fish Bull 97:62-72

Koeller PA (2000) Relative importance of abiotic and biotic factors to the management of the northern shrimp (Pandalus borealis) fishery on the Scotian Shelf. J Northw Atl Fish Sci 27:21-33

Koeller P (2006) Inferring shrimp (Pandalus borealis) growth characteristics from life history stage structure analysis. J Shell Res 25: 595-608

Koeller P, Covey M, King M (2006) An assessment of the eastern Scotian Shelf shrimp stock and fishery for 2005 and outlook to 2006. DFO Can Sci Adv Sec Res Doc 2006/001 
Koeller PA, King M, Newell MB, Newell A, Roddick D (1995) An inshore shrimp trap fishery for eastern Nova Scotia? Can Tech Rep Fish Aquat Sci No 2064

McCleese DW, Wilder DG (1958) The activity and catchability of the lobster (Homarus americanus) in relation to temperature. J Fish Res Board Canada 15(6): 1345-1354

Parsons DG, Sandeman EJ (1981) Groundfish survey techniques as applied to abundance surveys for shrimp. In: Doubleday WG, Rivard R (eds) Bottom trawl surveys. Can Spec Publ Fish Aquat Sci 58

Schick D (1982) The shrimp trap - a better mousetrap? Maine Department of Marine Resources, Fisheries Research Laboratory, West Boothbay Harbour, Maine. Research Reference Document 82/10

Shumway SE, Perkins HC, Schick DF, Stickney AP (1985) Synopsis of biological data on the pink shrimp, Pandalus borealis Krøyer, 1838. FAO Fish Synop 144

Skúladóttir U, Pétursson G (1999) Defining populations of northern shrimp, Pandalus borealis (Kroyer 1938), in Icelandic waters using the maximum length and maturity ogive. Rit Fiskideildar 16:247-262

Stein M (2000) Hydrographic and atmospheric conditions off east Greenland - their potential effects on the distribution of shrimp (Pandalus borealis). J Northw Atl Fish Sci 27:63-67

Subramanyam M (1965) Lunar, diurnal and tidal periodicity in relation to the prawn abundance and migration in the Godavari estuarine systems. Fish Technol 2(1):26-33 